\title{
Experience Outside of Clinical Trial with Everolimus
}

\author{
Beatriz Losada Vila*, Diego Malon Gimenez, Laura Rodríguez Lajusticia and Juan Antonio Guerra Martinez \\ Medical Oncologists, Fuenlabrada Hospital, Spain \\ Submission: September 03, 2018; Published: October 09, 2018 \\ "Corresponding author: Beatriz Losada Vila, Medical Oncologists, Fuenlabrada Hospital, Madrid, Spain, Email: beatriz.losada@salud.madrid.org
}

Keywords: Metastatic; Visceral; Chemotherapy; Letrozole; Hematological; Capecitabine.

\section{Introduction}

Luminal metastatic breast cancer has undergone a major breakthrough thanks to the emergence of mTOR inhibitors to the progression of aromatase inhibitors as shown by studies such as BELLE-2 and BOLERO-2 $(1,2)$. The aim of our study is to reflect the clinical characteristics of patients treated with ever olimus in our Hospital as well as the toxicity derived from them.

\section{Material and Methods}

Retrospective study of 5 patients diagnosed in the University Hospital of Fuenlabrada in treatment with ever olimus outside clinical trials during last 2 years.

\section{Results}

$100 \%$ of the patients are $<65$ years old ( 1 premenopausal, on treatment with gnRH analogue), with an ECOG 0-1 in 100\%. $40 \%$ started as a metastatic disease. Disease-free interval was greater than 2 years in $100 \%$ of the patients. $20 \%$ present 3 or more metastatic locations, while the remaining $80 \%$ present between 1-2 locations. $100 \%$ have visceral involvement. The indication of everolimus in the 5 patients was as much in 1 st line as in $2 \mathrm{nd}, 3 \mathrm{rd}$, 4 th and 5 th line. The patient who received everolimus in the first line was due to progression to aromatase inhibitor during the adjuvant setting. Regarding the treatments previously received, $60 \%$ were treated with fulvestrant, while also $60 \%$ had previously received chemotherapy for metastatic disease. $80 \%$ were on exemestane in combination with everolimus, while $20 \%$ combined it with letrozole. The starting dose of everolimus was $10 \mathrm{mg}$ in all patients. The median time on everolimus was 7.5 months (2-14), presenting in $60 \%(3 / 5)$ toxicity, being $2 / 3$ in the first 15 days and $1 / 3$ in the following 15-30 days. A patient continues with everolimus at present. The most frequently reported toxicity is as mucositis in $60 \%(2 / 3$ grade $3,1 / 3$ degree 2 ) that requires dose delay in all of them and dose reduction to $5 \mathrm{mg}$ in $2 / 3$. The second most frequent toxicity was pneumonitis $(2 / 5=40 \%$ grade 1 and 2 respectively). All patients received mouthwash with dexamethasone prior to the onset of everolimus. As a hematological toxicity, only grade 1 plaquetopenia stands out in $20 \%$. The maximum response was in the form of stability in $3 / 5(60 \%)$, no partial or complete reduction, while progression was in $2 / 5(40 \%)$ at the first reevaluation test $[1,2]$.

Treatment regimens that received the progression were hormonal therapy (fulvestrant) in 20\% while the remaining 60\% were on chemotherapy with nab paclitaxel, capecitabine or the combination of gemcitabine + vinorelbine. One patient (20\%) continues with everolimus as we presented previously.

\section{Conclusion}

a. The median time on everolimus was 7.5 months, requiring dose reduction to $5 \mathrm{mg}$ in $60 \%$ of patients.

b. The most frequently reported toxicity is as mucositis and pneumonitis.

c. The profile of patients who are being treated outside the clinical trial are patients $<65$ years with ECOG $0-1$ and several metastatic localizations (visceral involvement).

d. Chemotherapy is the treatment most used when progression.

\section{References}

1. Baselga J, Im SA, Iwata H, Clemons M, Yoshinori I, et al. (2015) PIK3CA Status in circulating tumour DNA predicts efficacy of buparlisib plus fulvestrant in postmenopausal women with endocrine-resistant HR+/ HER2- advanced breast cancer: first results from the randomized, phase III BELLE-2 trial. San Antonio Breast Cancer Symposium, S6-01.

2. Piccart M, Hortobagyi GN, Campone M, Pritchard KI, Lebrun FM, et al. (2014) Everolimus plus exemestane for hormone- receptor-positive, human epidermal growth factor receptor-2-negative advanced breast cancer: overall survival results from BOLERO-2. Ann Oncol 25(12): 2357-2362. 
Your next submission with Juniper Publishers will reach you the below assets

- Quality Editorial service

- Swift Peer Review

- Reprints availability

- E-prints Service

- Manuscript Podcast for convenient understanding

- Global attainment for your research

- Manuscript accessibility in different formats ( Pdf, E-pub, Full Text, Audio)

- Unceasing customer service

Track the below URL for one-step submission https://juniperpublishers.com/online-submission.php 